Volume 3 Nomor 2, 2018, hlm 96-100

DOI: https://doi.org/10.29210/300327700

ISSN: 2502-079X (Print)

ISSN: 2503-1619 (Electronic)

Info Artikel:

Diterima: $13 / 11 / 2018$

Direvisi: $10 / 12 / 2018$

Dipublikasikan: 22/12/2018

Dipublikasikan oleh:

Indonesian Institute for Counseling, Education and Therapy (IICET)

Akses Online :

http://jurnal.iicet.org/index.php/jrti

\title{
Meningkatkan kemampuan motorik kasar anak melalui tari kreasi tradisional mandahiling melayu di taman kanak-kanak al-muhsinin Pasaman barat
}

\author{
Erma Rosdiana \\ Universitas Negeri Padang \\ e-mail: ermarosdiana05@gmail.com
}

\begin{abstract}
The level of gross motor skills has not developed, where most children are still shy in moving their bodies, there are still children who are still in place and many irregular children move the body as a whole. The type of research is Classroom Action Research conducted by means of cycles, namely two cycles each cycle of three meetings. The learning outcomes in the initial conditions show that the gross motoric abilities of children have not yet developed and continued improvement in the first cycle through the Mandahiling Malay Traditional Creative Dance activities. In cycle II achieved optimal results with excellent results that Mandahiling Malay traditional creative dance can improve the gross motor skills of children in kindergarten Al-Muhsinin, West Pasaman.
\end{abstract}

Keywords: Rough motorik, mandahiling malay traditional creative dance

\section{PENDAHULUAN}

Anak usia dini adalah sosok yang sedang menjalani suatu proses perkembangan dengan pesat dan fundamental bagi kehidupan yang seanjutnya. Anak Usia Dini berada pada rentang usia 0-8 tahun. Proses pertumbuhan dan perkembangan dalam berbagai aspek yang sedang mengalami masa yang cepat dalam rentang perkembangan hidup manusia. Proses pembelajaran sebagai bentuk perlakuan yang diberikan pada anak yang harus memperhatikan karakteristik yang dimiliki setiap tahapan perkembangan anak.

Menurut Suyanto (2005) anak usia dini adalah: Anak yang sedang mengalami pertumbuhan dan perkembangan baik fisik maupun mental yang sangat pesat.makanan yang bergizi dan seimbang serta stimulasi pikiran sangat diperlukan untuk mendukung proes pertumbuhan dan 
perkembangan fisik dan motorik, moral, sosial, emosional, intelektual, dan bahasa. Usia ini disebut juga usia emas atau golden age (Rakimahwati, R., Lestari, N. A., \& Hartati, S. 2018).

Karakteristik anak usia dini mencakup usia antara empat sampai dengan enam tahun yang merupakan bagian dari perkembangan manusia secara keseluruhan Anak usia Taman Kanak-kanak tidak saja dipersiapkan untuk memasuki jenjang pendidikan Sekolah Dasar, tetapi yang lebih utama adalah supaya anak memperoleh rangsangan-rangsangan kemampuan dasar terhadap perkembangan bahasa, kognitif, fisik motorik dan seni, serta pengembangan pembiasaan yang terdiri dari nilai-nilai agama, sosial, emosional dan kemandirian (Putri, M., Rakimahwati, R., \& Zulminiati, Z, 2018).

Menurut Suryana (2014), karakteristik anak usia dini yaitu: (a) Bersifat egosentris, pada umumnya anak melihat dunia dari sudut pandang dan perkembangannya sendiri. (b) Memiliki rasa ingin tahu, anak beranggapan bahwa dunia ini penuh dengan hal-hal yang menarik dan menakjibkan. (c) Bersifat unik, anak memiliki keunikan sendiri seperti gaya dalam belajar, minat dan latar belakang keluarganya. (d) Anak kaya imajinasi dan fantasi, anak memiliki dunia sendiri berbeda dengan orang di atas usianya, mereka tertarik dengan hal-hal yang bersifat imajinasi sehingga mereka kaya akan fantasi.

Menurut Suryana (2016) pendidikan anak usia dini adalah suatu upaya pembinaan yang ditujukan kepada anak sejak lahir hingga usia 6 tahun yang dilakukan dengan pemberian rangsangan pendidikan untuk membantu pertumbuhan dan perkembangan jasmani dan rohani agar anak memiliki kesiapan dalam memasuki pendidikan lebih lanjut.

Perkembangan fisik menggambarkan perubahan dalam penampilan fisik anak-anak, sama seperti dalam keterampilan motorik. Prestasi fisik yang penting pada anak di masa ini adalah bertambahnya kontrol terhadap gerakan-gerakan motorik dari yang tidak karuan menjadi teratur dan terarah (Rakimahwati, R., \& Marlina, S, 2018). Motorik kasar erat hubungannya dengan jasmani maka diperlukan tubuh sehat, kuat, cekatan, melakukan gerakan-gerakan baik berlari, meniti, bergelantungan, merangkak, merayap. Kalau anak terampil melakukan kegiatan-kegiatan tersebut, ia akan lebih percaya diri dan mampu melakukan gerakan-gerakan yang lebih sulit (Rakimahwati. R, 2018 \& Rakimahwati. R, 2014)).

Menurut Umama (2016) Motorik kasar adalah kemampuan anak yang digunakan untuk mengontorl otot-otot besar, meliputi kemampuannya untuk duduk, berjalan, berlari, menendang, melompat, melempar. Anak usia dini tubuhnya lebih lentur dibandingkan orang dewasa sehingga mereka lebih mudah melenturkan otot-ototnya dan mengikuti gerakan-gerakan akrobatik. Selain itu juga anak sangat suka dengan pengulangan, mereka akan bersedia mengulangi suatu tindakan hingga pola otot terlatih untuk melakukannya secara efektif.

Berdasarkan observasi awal di kelasa B Taman Kanak-kanak Al Muhsinin, tempat peneliti mengajar terlihat tingkat kemampuan motorik kasar belum berkembang secara optimal.Ini terlihat pada saat terjadi proses pembelajaran, anak yang seharusnya memperagakan gerakan menari dengan melangkah maju, mundur, berjinjit dan melompat malah duduk berlari kesana kemari.

Permainan yang digunakan guru belum maksimal seperti anak hanya bermain kejar-kejaran sehingga untuk mengembangkan kemampuan motorik kasar anak sehingga anak kurang mampu berdiri menyeimbangkan badan,kurang mampu menyeimbangkan badan pada garis lurusserta anak kurang mampu menyelesaikan gerakan berpariasidengan media yang disediakan guru dan kurang menarik minat atau perhatian anak,sehingga anak kurang semangat untuk melakukan pergerakan otot-ototnya, maka penulis tertarik untuk melakukan perubahan terhadap metode mengajar guru dalammengembangkan kemampuan anak terutama dalam motorik kasar dengan menggunakan permainan yang menarik. Hal ini disebabkan karena penggunaan metode pembelajaran guru kurang tepat, sehingga kebanyakan anak lebih suka duduk dari pada memperagakan gerakan dasar Tari Kreasi Tradisional Mandailing Melayu.

Mengatasi hal tersebut maka digunakan metode bermain sambil belajar untuk mengembangkan kemampuan motorik anak,guru dapat menetapkan metode bermain sambil belajar yang menjamin anak tidak mengalami cedera.Oleh karena itu,guru perlu menciptakan lingkungan yang aman dan menentang,bahan dan alat yang dipergunakan dalam keadaan baik,serta tidak menimbulkan rasa takut dan cemas dalam memainkannya.

Bermain merupakan kegiatan atau aktifitas yang tidak terlepas dari dunia anak (Rakimahwati, R. 2017. Dengan bermain anak akan meningkatkan kemampuannya dan mengembangkan dirinya. Bermain merupakan kegiatan yang terjadi secara alamiah dan anak tidak perlu dipaksa untuk bermain, karena bermain merupakan suatu kebutuhan dan kegiatan yang menyenangkan bagi anak, 
sehingga anak tingkat kemampuan motorik kasar anak melompat dengan dua kaki, melompat dengan satu kaki, anak belum mampu berdiri di atas satu kaki serta melemparkan benda sesuai dengan objek sasaran dapat teratasi dengan bermain karena bermain merupakan kegiatan yang terjadi secara alamiah pada anak yang berguna membantu anak memahami dan mengungkapkan dunianya, baik dalam taraf berfikir maupun perasaan. Serta memberikan anak perasaan menguasai atau mampu mengendalikan hal-hal yang ada dalam dunianya dan kegiatan yang tidak terikat realitas, sehingga anak dapat mengubah-ubah minatnya dimana hal ini juga penting dalam perkembangan pemahaman mereka.

Sedangkan menurut Elida dalam Mulyadi (2004), bermain merupakan suatu aktivitas yang mambantu anak mencapai perkembangan yang utuh baik fisik, intelektual, social, moral, dan emosional. Banyak konsep dasar yang bisa dipelajari atau diperbolehkan untuk anak usia dini melalui bermain. Salah satunya Tari Kreasi Tradisional Mandailing Melayu..Anak usia Taman Kanak-kanak mempunyai rentang perhatian yang terbatas sehingga anak masih sulit belajar dengan serius dan masih sulit diatur tapi bila pengembangan motorik kasar tersebut dilakukan sambil bermain maka anak akan merasa senang, diharapkan anak dapat melompat, berdiri di atas satu kaki maupun melempar.

\section{METODOLOGI PENELITIAN}

Jenis Penelitian yang digunakan pada penelitian ini adalah metode penelitian tindakan kelas (PTK) atau Classroom Action Research (CAR) (Sanjaya, D. H. W, 2016). Penelitian ini bertempat di Taman Kanak-kanak Al- Muhsinin Pasaman Barat. Sedangkan waktu penelitian ini dilaksanakan pada Semester I bulan Juli-Agustus 2018, Tahun Pelajaran 2018/2019. Subjek penelitian adalah anak didik kelompok B Taman Kanak-kanak Al- Muhsinin Pasaman Barat, semester I, tahun pelajaran 2018/2019 yang berjumlah 15 orang anak, terdiri dari 10 orang anak perempuan dan 5 orang anak laki-laki. Data yang akan diperoleh selama pembelajaran diolah dengan teknik persentase yang dikemukakan Arikunto (2007).

\section{HASIL}

Berdasarkan jumlah anak dalam pelaksanaan peningkatan motorik kasar melalui permainan Bakiak Tampuruang dimana pada observasi terhadap anak setelah tindakan dilakukan, maka diperoleh kesimpulan bahwa siklus I belum mencapai Kriteria Ketuntasan Minimum (KKM) yaitu sebesar $75 \%$ yang telah ditetapkan dengan demikian peneliti perlu melakukan tindakan penelitian siklus II. Setelah tindakan dilakukan pada siklus II, maka diperoleh kesimpulan bahwa siklus II telah mencapai Kriteria Ketuntasan Minimum (KKM) yang telah ditetapkan.

Keberhasilan meningkatkan kemampuan motorik kasar anak melalui Tari Kreasi Tradisional Mandahiling Melayu dengan nilai BSB (Berkembang Sangat Baik) dapat dijabarkan sebagai berikut :

Tabel 1. Persentase Hasil Observasi Meningkatkan Kemampuan Motorik Kasar Anak Melalui Tari Kreasi Tradisional Mandahiling Melayu pada Kategori BSB (Berkembang Sangat Baik)

\begin{tabular}{clcc}
\hline No & \multicolumn{1}{c}{ Aspek Yang Diamati } & Siklus I & Siklus II \\
\hline 1. & Anak mampu melangkah sesuai dengan irama music & $34 \%$ & $93 \%$ \\
2. & Anak mampu melompat sesuai irama music & $27 \%$ & $87 \%$ \\
3. & $\begin{array}{l}\text { Anak mampu bergerak maju mundur mengikuti irama } \\
\text { music }\end{array}$ & $20 \%$ & $80 \%$ \\
\hline
\end{tabular}

Berdasarkan tabel di atas persentase hasil observasi meningkatkan kemampuan motorik kasar anak melalui Tari Kreasi Tradisional Mandahiling Melayu pada kategori BSB (Berkembang Sangat Baik) pada: Aspek pertama anak mampu melangkah sesuai dengan irama musik, pada siklus I dengan persentase sebesar 34\% dan mengalami kenaikan menjadi $93 \%$ pada siklus II. Aspek kedua anak mampu melompat sesuai irama musik, pada siklus I dengan persentase sebesar $27 \%$ dan mengalami kenaikan menjadi $87 \%$ pada siklus II. Aspek ketiga anak mampu bergerak maju mundur mengikuti irama musik, pada siklus I dengan persentase sebesar $20 \%$ dan mengalami kenaikan menjadi $80 \%$ pada siklus II. 
Lebih jelasnya dapat dilihat pada grafik dibawah ini :

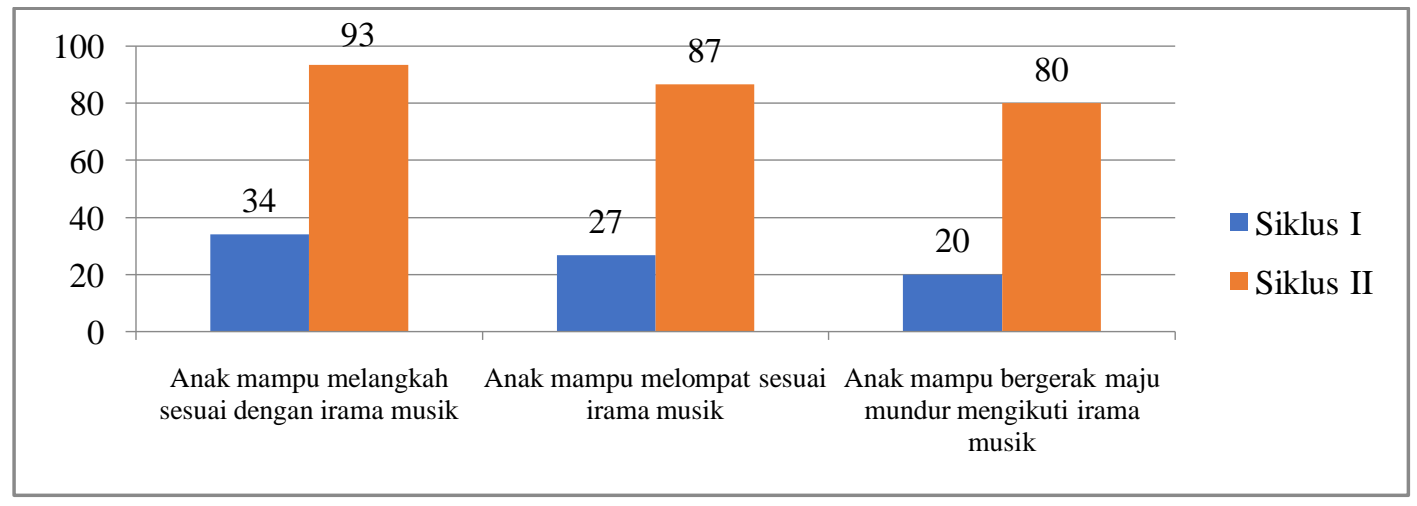

Gambar 1. Persentase Hasil Observasi Meningkatkan Kemampuan Motorik Kasar Anak Melalui Tari Kreasi Tradisional Mandahiling Melayu pada Kategori Sangat Baik

\section{PEMBAHASAN}

Hasil yang diperoleh maka dilakukan perbaikan pada siklus II, karena semua indikator telah tercapai dengan hasil sangat baik, peningkatan terjadi karena peneliti melakukan bimbingan kepada anak secara individu terutama kepada anak secara individu terutama bagi anak yang masih mengalami kesulitan. Hal ini menandakan bahwa Tari Kreasi Tradisional Mandahiling Melayu dapat meningkatkan kemampuan motorik kasar anak sesuai dengan pendapat Hurlock dalam Wuryani (2008: 2.14) perkembangan motorik adalah perkembangan pengendalian gerakan jasmaniah melalui kegiatan pusat syaraf, urat syaraf dan otot yang terkoordinasi. Ketiga unsur tersebut melaksanakan masing-masing perannya secara interaksi positif, artinya unsur yang satu saling berkaitan, saling menunjang, saling melengkapi dengan unsurnya untuk mencapai kondisi motorik yang lebih sempurna keadaannya. Anak yang otaknya mengalami gangguan tampak BB (Belum Berkembang) terampil menggerak-gerakkan tubuhnya.

Melalui siklus I terlihat perkembangan motorik kasar anak melalui Tari Kreasi Tradisional Mandahiling Melayu belum meningkat dengan baik, karena masih banyak anak yang tidak percaya diri dengan kemampuan yang dimilikinya, tingkat keberhasilan anak pada siklus I belum mencapai nilai sangat baik, sedangkan pada siklus II perkembangan motorik kasar anak meningkat dengan BSB (Berkembang Sangat Baik) karena di siklus II ini akan yang memperoleh nilai sudah tidak ada lagi anak yang memperoleh nilai BB (Belum Berkembang), sehingga keberhasilan anak pada aspek ini telah melebihi Kriteria Ketuntasan Minimal (KKM) yaitu 75\%.

Berdasarkan uraian di atas dapat disimpulkan penelitian tindakan kelas melalui Tari Kreasi Tradisional Mandahiling Melayu dapat meningkatkan kemampuan motorik kasar anak dan dapat memberikan sumbangan positif terhadap peningkatan pembelajaran.

\section{SIMPULAN DAN SARAN}

Berdasarkan hasil penelitian dan pembahasan yang telah diuraikan pada bab sebelumnya, maka dapat diambil kesimpulan dan saran sebagai berikut : Meningkatkan kemampuan motorik kasar anak di Taman Kanak-kanak Al-Muhsinin Pasaman Barat perlu dikembangkan, salah satunya adalah dengan cara menggunakan tari kreasi tradisional Mandahiling Melayu. Meningkatkan kemampuan motorik kasar anak melalui tari kreasi tradisional Mandahiling Melayu dapat berkembang dengan baik apabila didukung dengan sarana dan prasarana belajar di Taman Kanak-kanak serta adanya motivasi dari dalam dan luar diri anak. Metode yang digunakan dalam penelitian ini adalah Penelitian Tindakan Kelas dimana peneliti langsung meneliti anak tentang peningkatan motorik kasar anak selama proses belajar berlangsung dan berkolaborasi dengan teman sejawat. Setelah dilaksanakan penelitian pada siklus II terlihat peningkatan indikator keberhasilan dibandingkan dengan siklus I terbukti dari hasil yang diperoleh mengenai peningkatan motorik kasar anak pada masing-masing indikator yang telah ditetapkan maka anak yang mendapatkan nilai Berkembang Sangat Baik (BSB) pada akhir siklus I dengan persentase 
$31 \%$ dan terus mengalami kenaikan menjadi $87 \%$ pada akhir siklus II ini menandakan bahwa dengan tari kreasi tradisional Mandahiling Melayu dapat meningkatkan motorik kasar anak

Berdasarkan kesimpulan di atas, ada beberapa saran yang ingin diuraikan sebagai berikut : Pihak sekolah sebaiknya menyediakan sarana permainan yang dapat meningkatkan motorik kasar anak. Hendaknya guru menggunakan berbagai macam metode dalam memberikan kegiatan pembelajaran, dengan begitu anak tidak akan merasa jenuh dalam belajar serta tujuan pembelajaran akan tercapai secara optimal. Diharapkan kepada Dinas Terkait untuk memberikan perhatian yang besar dalam peningkatan motorik kasar anak di Taman Kanak-kanak Al-Muhsinin Pasaman Barat pada khususnya dan Kecamatan Sungai Aur pada umumnya Bagi peneliti yang lain diharapkan dapat mengembangkan peningkatan motorik kasar anak melalui metode dan sarana pembelajaran yang lainnya Bagi pembaca diharapkan dapat menggunakan skripsi ini sebagai sumber ilmu pengetahuan guna menambah wawasan.

\section{DAFTAR PUSTAKA}

Arikunto, Suharsimi. (2007). Penelitian Tindakan Kelas. Jakarta: Bumi Aksara.

Mulyadi, (2004). Mengembangkan Bakat dan Kreativitas Anak. Jakarta: Gramedia

Putri, M., Rakimahwati, R., \& Zulminiati, Z. (2018). Efektivitas Penerapan Metode Bermain Peran Makro terhadap Perkembangan Bahasa Lisan Anak di Taman Kanak-kanak Darul Falah Kota Padang. Journal of Studies in Early Childhood Education (J-SECE), 1(2), 171-179.

Rakimahwati, R. (2018). Pelatihan Pembuatan Boneka Jari Bergambar dalam Meningkatkan Kemampuan Membaca Anak Usia Dini Di Kecamatan V Koto Kampung dalam Kabupaten Padang Pariaman. Early Childhood: Jurnal Pendidikan, 2(2b), 1-11.

Rakimahwati, R. (2017). Interactive Game Influences Based on Inquiry Learning Model Towards The Ability of Reading in Kindergarten in Padang. In International Conference of Early Childhood Education (ICECE 2017). Atlantis Press.

Rakimahwati, R. (2014). Character Development through Dance Learning in an Early Childhood Setting. Indonesian Journal of Early Childhood Education Studies, 3(2), 102-107.

Rakimahwati, R., \& Marlina, S. (2018). Pengaruh Media Busy Book Terhadap Kemampuan Berhitung Anak Usia Dini Di Taman Kanak-Kanak Fadhilah Amal 3 Padang. Jurnal Usia Dini, 4(2), 8-17.

Rakimahwati, R., Lestari, N. A., \& Hartati, S. (2018). Pengaruh Kirigami Terhadap Kemampuan Motorik Halus Anak di Taman Kanak-Kanak. Jurnal Obsesi: Jurnal Pendidikan Anak Usia Dini, 2(1), 102-110.

Sanjaya, D. H. W. (2016). Penelitian tindakan kelas. Prenada Media.

Suryana, Dadan (2014). Modul 1 Dasar-dasar Pendidikan Anak TK. Tangerang Selatan:UT

Suryana, Dadan (2016). Pendidikan Anak Usia Dini stimulasi \&aspek perkembangan Anak. Jakarta. Kencana

Suyanto, Slamet. (2005). Pembelajaran untuk Anak TK. Jakarta: Depdiknas, Dikti.

Umama (2016) .Pojok Bermain Anak. Jogjakarta: CV. Diandra Primamitra Media

Wuryani (2008). Dasar-dasar Pengembangan Motorik. Jakarta: Salemba. 